Meta

Journal des traducteurs

Translators' Journal

\title{
Pragmatic and Syntactic Features of Topics in American Sign Language
}

\section{Terry Janzen}

Volume 42, numéro 3, septembre 1997

L’interprétation en langues des signes

URI : https://id.erudit.org/iderudit/003254ar

DOI : https://doi.org/10.7202/003254ar

Aller au sommaire du numéro

\section{Éditeur(s)}

Les Presses de l'Université de Montréal

\section{ISSN}

0026-0452 (imprimé)

1492-1421 (numérique)

Découvrir la revue

\section{Citer cet article}

Janzen, T. (1997). Pragmatic and Syntactic Features of Topics in American Sign Language. Meta, 42(3), 502-513. https://doi.org/10.7202/003254ar

\section{Résumé de l'article}

En ASL, les phrases suivent un ordre thème-rhème différent de l'ordre sujet prédicat des langues orales. Les marques thématiques sont souvent mal comprises, aussi la présente étude les examine-t-elle dans le discours. Il apparaît qu'en ASL, le sens a une double origine. Tout d'abord le contexte pragmatique, extérieur à $\mathrm{F}$ acte de discours, puis la structure syntaxique à même le discours. Les marques thématiques en ASL sont des éléments grammaticaux qui révèlent la stratégie de communication de l'orateur. Elles codent l'information que celui-ci suppose être connue, ou tout au moins identifiable par les personnes auxquelles il s'adresse. Les marques thématiques telles que sourcils relevés ou tête légèrement rejetée en arrière sont des signes associés aux questions qui appellent des réponses, oui I non. La présente étude montre que les marques thématiques et les signes qui appellent un oui I non ont une structure propositionnelle et une fonction proche, mais que les questions oui/ non exigent une participation interactive plus poussée de la part des interlocuteurs. La présente étude se fonde sur deux textes narratifs en ASL, codés de façon à dégager leurs marques thématiques et non thématiques. Nous avons examiné leurs traits spécifiques aussi bien que leur teneur structurale et sémantique, et il s'avère que dégager les origines pragmatiques risque de ne pas être aussi facile que les sources pragmatiques. Dans la mesure où ils ne sont pas les destinataires directs de l'information, ils risquent de ne pas comprendre le discours aussi bien que les destinataires directs, et de faire une interprétation moins précise. S'ils comprenaient mieux les structures grammaticales de VASL, les interprètes comprendraient également mieux les intentions de l'auteur et se rendraient compte que la codification de l'information se fait par des éléments thématiques aussi bien que par des éléments non thématiques. La présente étude s'efforce de fournir aux interprètes une meilleure appréhension de la grammaire des signes.
Ce document est protégé par la loi sur le droit d'auteur. L’utilisation des services d'Érudit (y compris la reproduction) est assujettie à sa politique d'utilisation que vous pouvez consulter en ligne.

https://apropos.erudit.org/fr/usagers/politique-dutilisation/ 


\title{
PRAGMATIC AND SYNTACTIC FEATURES OF TOPICS IN AMERICAN SIGN LANGUAGE*
}

TERRY JANZEN

University of New Mexico, Albuquerque, United States

\begin{abstract}
Résumé
En ASL, les phrases suivent un ordre thème-rhème différent de l'ordre sujet prédicat des langues orales. Les marques thématiques sont souvent mal comprises, aussi la présente étude les examine-t-elle dans le discours. Il apparaît qu'en ASL, le sens a une double origine. Tout d'abord le contexte pragmatique, extérieur à l'acte de discours, puis la structure syntaxique à même le discours.

Les marques thématiques en ASL sont des éléments grammaticaux qui révèlent la stratégie de communication de l' orateur. Elles codent l' information que celui-ci suppose être connue, ou tout au moins identifiable par les personnes auxquelles il s'adresse. Les marques thématiques telles que sourcils relevés ou tête légèrement rejetée en arrière sont des signes associés aux questions qui appellent des réponses, oui / non. La présente étude montre que les marques thématiques et les signes qui appellent un ouil non ont une structure propositionnelle et une fonction proche, mais que les questions ouil non exigent une participation interactive plus poussée de la part des interlocuteurs.

La présente étude se fonde sur deux textes narratifs en ASL, codés de façon à dégager leurs marques thématiques et non thématiques. Nous avons examiné leurs traits spécifiques aussi bien que leur teneur structurale et sémantique, et il s'avère que dégager les origines pragmatiques risque de ne pas être aussi facile que les sources pragmatiques. Dans la mesure où ils ne sont pas les destinataires directs de l'information, ils risquent de ne pas comprendre le discours aussi bien que les destinataires directs, et de faire une interprétation moins précise. S'ils comprenaient mieux les structures grammaticales de l'ASL, les interprètes comprendraient également mieux les intentions de l'auteur et se rendraient compte que la codification de l'information se fait par des éléments thématiques aussi bien que par des éléments non thématiques. La présente étude s'efforce de fournir aux interprètes une meilleure appréhension de la grammaire des signes.
\end{abstract}

\begin{abstract}
American Sign Language (ASL) sentences are understood as constructed around a topic-comment, rather than a subject-predicate, relation, but topic constituents are not well understood. This study examines topic-marked constituents in the context of discourse negotiation, suggesting that there are two sources for semantic material that is coded as topics in ASL. These are first, pragmatic contexts that are external to the discourse event, and second, the syntactic structure of the discourse itself.

This study is based on two ASL narrative texts which were coded for topic and nontopic constituents and seeks to familiarized the interpreter with the grammatical structure of ASL. This way, the interpreter has a better grasp of the signer's perspective on the information coded both by topics and non-topics in the discourse.
\end{abstract}

\section{INTRODUCTION}

American Sign Language (ASL) is the signed language most widely used in both Canada and the United States. The grammar of ASL, like that of other signed languages, 
exploits the three-dimentional space immediately in front of the signer, which is where many of the components of a signed language are produced. Signed languages are conveyed through the visual, rather than the auditory, channel - the addressee must see the signer, and likewise, the signer appears to need to see the addressee.

Linguistic description of ASL has a relatively brief history, beginning with William C. Stokoe's work on ASL phonology in the late 1950s. Much attention has since focussed on accurate and detailed description of the phonetics and phonology of ASL as a signed, rather than a spoken, language, as well as on the morphology of the language. Comparatively little has been written about sentence structure, although this has received more attention in recent years, and several works (e.g. Baker and Cokely 1980) have included a general description of phrase and sentence structure.

The present study investigates how the notion of topicality is coded in the syntax of ASL. ASL is generally recognized as having "topic-comment" structure as a possible sentence structure, although its function has not been well understood. Baker and Cokely (1980), for example, consider it as one possible sentence type, along with questions, commands, conditionals, negation and assertion. In Janzen (1995a), however, I argue that topic marking is much more basic to ASL grammar than Baker and Cokely's relegation to sentence type indicates. Many sentence types contain topic-marked constituents, which suggests that it is something much more basic to the grammar than simply a possible sentence type of the sort listed above.

In this study, I discuss topic-comment structure in ASL within the context of discourse negotiation, and examine how semantic material becomes available for topic marking. Specifically, I suggest that the signer has two sources in this regard, pragmatic information, and the syntactic structure of the discourse event. Second, I look at the interpreter's position in situations where interaction between interlocutors is mediated by interpretation. The interpreter is not the intended recipient of information in such interaction, and therefore may not be in a position to actively negotiate the advancement of the information exchange with a high degree of accuracy.

\section{TRADITIONAL NOTIONS ABOUT TOPIC-COMMENT STRUCTURES IN ASL}

Because the grammars of ASL most widely used by interpretation students treat topic-comment structure as one of several sentence types, and because a more complete linguistic discussion of the functions of topic marking in ASL has yet to be undertaken, interpreters have the potential both to misunderstand how Deaf signers are using topiccomment structure, and to use the structure in ungrammatical ways themselves. It is commonly thought that the signer can choose virtually anything they wish to be in the topic constituent, depending of course, on what the signer is talking about. This leads to the notion that what is marked as topic in an ASL sentence is the "focus" of the sentence. Further, and perhaps additionally because of the way that English employs the occasional topic phrase, as in the clefted sentence in (1), it could be construed that topic-marking is a good mechanism for emphasizing something in the sentence.

(1) It was John who borrowed the book from me.

Topic marking does not have an emphatic role in ASL, however, and neither does it code the sentence focus, although the terminology "topic" and "focus" might confuse the issue if used in a broad and non-technical way. To be fair, many interpreters do have a sense that topics code the discourse "theme", but even in this, it is unlikely that they will be able to articulate how this notion relates to particular sentence structures, and how knowing what the theme is restricts their choice of constituents that may be topic-marked. 
It would be helpful to understand more clearly the role that topic marking plays in ASL discourse. The next section provides a brief discussion of topic-comment structure as I understand it, and this is followed by an analysis of the structure and function of topic-marked sentence constituents taken from two ASL narratives.

\section{TOPIC-COMMENT STRUCTURE IN ASL}

Haiman (1978) characterizes topics as something extra-linguistic agreed upon by speaker and addressee, constituting a framework selected for the discourse to follow. The topic is information that the speaker presupposes the addressee to know, sometimes referred to as "old" information, whereas "new" information is something that the speaker cannot presuppose the addressee to know, and is in fact the purpose for the proposition in the first place (Givón 1984). Givón suggests that each proposition in a discourse is a combination of old and new information. Some old information is necessary to link the sentence to those which have come before it, whereas new information adds to the "data-base" of information built up in the discourse. Too much old information makes the discourse redundant. Too much new information makes the discourse incoherent. A balance, therefore, of old and new information must be struck.

Some other languages, such as Mandarin Chinese, have been described as topicprominent ( $\mathrm{Li}$ and Thompson 1976). $\mathrm{Li}$ and Thompson characterize topics in topicprominent languages as discourse elements rather than strictly sentential elements, of having no restriction that they must be arguments of the verb, of being consistently sentenceinitial elements (differing from subjects, which in many languages are not in first position), and of occurring in sentences where subjects also appear (so-called "double subject" sentences). Examples (2) and (3) from Mandarin illustrate several of these characteristics.

(2) chū-qu hē chá wo qing ni exit-go drink tea I invite you 'Going out for tea (topic), I'll invite you.'

$$
\text { (Li and Thompson 1981: 98) }
$$

(3) nèi- chang huo xíngkui xiaofang-duì laí de kuài that-CL fire fortunate fire- brigade come adv.particle quick 'That fire (topic), fortunately the fire-brigade came quickly.' (Li and Thompson 1976: 462)

In (2) a context for the main proposition is set up in the topic, whereas both arguments (subject and object) of the verb qing 'invite' are in the comment. An even better example of a sentence where the topic, an NP, is not in an argument relationship with the verb is (3). In this sentence, huo 'fire' is not the subject of lai 'come', which occurs much later in the comment. Both of these topics are sentence-initial, and although there are optional topic marking morphemes in Mandarin ( $\mathrm{Li}$ and Thompson 1981), they do not appear in (2) or (3), and neither is there any other morphology to link the topic constituent to the rest of the sentence. $\mathrm{Li}$ and Thompson argue that this sentence structure is basic to Mandarin, and therefore the markedness characteristic of topicalization in English is not suggested. For English, a seemingly equivalent sentence as in (4) is a highly marked construction, one that places explicit emphasis on the fire, something that the Mandarin sentence (3) does not do.

(4) As for that fire, fortunately the fire-brigade came quickly.

In ASL, as in Mandarin, many types of constituent can be in topic position. Some researchers have tended to focus on NPs as typical topics (e.g. Friedman 1976), although Baker and Cokely (1980) suggest that topics can be persons, objects, places, times and 
events. A number of authors illustrate topic-type sentences almost exclusively with objectlike NPs in topic position (e.g. Valli and Lucas 1995). In Janzen (1995b) I argue that temporal adverb phrases make particularly good topics because they situate events within a temporal framework, as (5) demonstrates. ASL topics are thought to be clause-initial, and are prototypically marked with raised eyebrows and perhaps a slight backward head tilt (Baker and Cokely 1980, Valli and Lucas 1995). The last sign of the topic may be held slightly longer, and there may be a pause between the topic and comment constituents.

(5) NEXT.WEEK, FUTURE SEE B-I-L-L'
'I'll see Bill next week.'

(Janzen 1995b: 52)

However, as (6) shows, there is pragmatic discourse motivation in the choice of topic.

(6) KNOW B-I-L-L, FUTURE SEE NEXT.WEEK 'I'll see Bill next week.'

(Janzen 1995b: 53)

The main difference between these two sentences has to do with how the signer is negotiating the discourse with the addressee. In (5) the signer is using time to situate the event, whereas in (6) the signer cannot proceed with the proposition until it is clear that both he and the addressee share certain information. Thus it is this presupposed information that is marked as topic. It could also be argued that the structure of (6) is appropriate when the (negotiated) NP B-I-L-L is the framework for the proposition, and the new information is the time and the event. (6) is also an example of the type of topic that may open a discourse event, in which case the signer is clearly bringing some presupposed shared information into the discourse whose source is external to that discourse.

One further example is of interest. In (7) we have an entire clause marked as topic, similar to the Mandarin example in (2).

(7) MAN BRING BOOK, DOUBT

'I doubt that the man is bringing the book.'

(Janzen 1995a: 68)

In (7) the main verb is DOUBT, and in this example, the first person subject is null. It is the entire subordinate clause that is marked as topic and must be understood as the framework for the proposition.

From this brief discussion it is clear that topic marking in ASL goes well beyond the common notion that NPs, and more specifically object NPs, are typically in topic position. The nature of topic marking must be further investigated. How much topic marking is there in ASL discourse? Do some types of constituent emerge as prototypical topics? And finally, what are the functions of topic marking in ASL? Givón (1984: 270) suggests that it is "common for the same coding unit, say a morpheme, to code a cluster of lexical, propositional and discourse functions (italics his)." This appears to be the case for topic marking in some languages. Haiman (1978) discusses the morpheme -ve in Hua, a Papuan language, as marking topics, yes/no questions, conditionals and non-exhaustive conjunction. Haiman also cites Turkish and Tagalog as languages in which topics and conditionals are marked similarly.

The remainder of this discussion focusses on marked topics in two ASL texts. Particular attention is paid to the frequency of topic-marking, the types of constituents 
marked as topics, and the source of the topic-marked information as it relates to the flow of discourse, that is, whether the information coded has a pragmatic source external to the immediate discourse or a source within the actual structure of the discourse.

\section{THE ASL TEXTS}

In this study two ASL narrative texts were coded for topic-marked and non-topic constituents. ${ }^{2}$ The texts were chosen from a professionally produced videotape for a Red River Community College (Winnipeg, Canada) course in the ASL/English Interpretation Program entitled "Building Translation Skills: ASL." Both signers are Deaf ${ }^{3}$ with ASL as their first language. Text $\mathrm{A}$ is a rather informal personal account of a frightening experience that took place when the signer was a teenager, and would be the kind of story related during casual conversation. Text $\mathrm{B}$ is a more technical description of the nature of, and theory behind, a set of skills that must be learned by a group of students. Text $B$ is a more formal text than Text A.

For each text, the total number of clauses were counted ( 140 for Text A; 85 for Text B), as were the total number of topic-marked constituents ( 48 for Text A $(34.3 \%) ; 45$ for Text $\mathrm{B}(52.9 \%))$. These figures may be considered somewhat approximate, considering that for a language whose grammar must take into account three-dimensional space, clause boundaries are not always clearly definable, especially in more complex sentences. As well, it appears that an ASL sentence does not necessarily require an overt verb. This being the case, a clause in this study is taken to be a string that includes either a verbal or stative predicate, or is understood to be propositional.

In connected discourse, at least for these two texts, topic marking appears not to be entirely categorical, that is, while many topic-marked constituents do conform to the description of topic characteristics above, some are less prototypical. A constituent in these texts was counted as a topic if the constituent included facial topic marking. Topics less prototypical were found, for example several received the appropriate facial markers, but were not in clause-initial position. Nonetheless, these were counted as topics. ${ }^{4}$ Table 1 gives the proportion of topic constituents for each of the texts.

\begin{tabular}{|l|c|c|}
\hline Topic constituent: & Text A: & Text B: \\
\hline Full NP subject & $16(33.3 \%)$ & $2(4.4 \%)$ \\
\hline Pronominal subject & $3(6.3)$ & $1(2.2)$ \\
\hline Full NP object & $2(4.2)$ & $1(2.2)$ \\
\hline Pronominal object & 0 & 0 \\
\hline Non-argument NP & $8(16.7)$ & $1(2.2)$ \\
\hline Time adverbs & $3(6.3)$ & $2(4.4)$ \\
\hline Discourse markers & 0 & $7(15.6)$ \\
\hline Clause linkage & $3(6.3)$ & $9(20.0)$ \\
\hline Full clauses & $11(22.9)$ & $22(48.9)$ \\
\hline Other & $2(4.2)$ & 0 \\
\hline Total: & 100.0 & 100.0 \\
\hline
\end{tabular}

TABLE 1:

Number of topic-marked constituent type for Texts A and B, with percentages in parentheses (percentages were rounded to one decimal place). 
While it is not the focus of this study to discuss each of the topic types reported in Table 1 in detail, it should be noted that there are differences in the relative proportion of topic types between these two signers. This could be attributed to differences in register, the discourse style of the signers, or any other factor or combination of factors. This effect is not discussed further here, except to suggest that such differences warrant further investigation, and that a better understanding of these differences would be of particular interest to students of interpretation.

One of the most striking features in the two texts regarding marked topics is the lack of objects in topic position. Altogether, there were only 3 full NP objects (3.2\% of all topics in Texts A and B combined) and no pronominal objects marked as topics. This is interesting considering that an object of the verb is often cited as a very basic kind of topic in ASL, and is perhaps traditionally thought of as prototypical. If these texts are representative of typical ASL narrative, however, this is not the case. While interesting, it should perhaps not be too surprising, since in languages generally subjects tend to be more topical, whereas grammatical objects tend to represent the new information.

This fact about subjects is also borne out in the texts examined here. A total of 22 subject NPs (23.6\%) in Texts A and B combined were also marked as topics. (Non-argument NPs marked as topics were also higher, with a combined total of $9.7 \%$.) Note that these percentages support the notion that there is no requirement that the subject of the sentence and the topic of the sentence be one and the same element in ASL. Discourse markers, such as event-sequencing elements, and clause linkage markers, such as BUT and in some circumstances FINISH, are also listed in Table 1, but are not discussed here.

As mentioned above, time references make good topics in ASL. These two texts, however, show a low overall proportion of such constituents $(5.4 \%)$. But neither of these texts involve much movement between time references. In Text $\mathrm{A}$, for example, the time reference when the story takes place is introduced as new information, as shown in (8). Three times subsequently, the story-teller uses the phrase THAT ERA 'at that time' each of which is topic marked. (9) is one such example, in which the signer is giving some general information about the evening (the weather) that is relevant to the story, and the phrase is topic-marked because first, the audience has already been introduced to the evening in question and so the topic is identifiable, and second, time references are amenable to topic-marking generally, as mentioned above.

(8) $\frac{\mathrm{t}}{\text { PRO.1 YOUNG AGE APPROX SIXTEEN SEVENTEEN APPROX }}$

'I was about sixteen or seventeen years old.'

(9) THAT ERA, SNOW AND RAIN

'At that time it was both snowing and raining.'

Note that the first person pronoun in (8) is already topical, as a pronoun, but is identified as the topic of this particular sentence. The signer has just begun her story, and has already told her audience that it is a story about herself.

Sentence (9) is a good example of topic-comment structure in ASL. The comment SNOW AND RAIN relates to the topic THAT ERA by virtue of the sentence structure itself, and not by additional lexical or grammatical morphology in the sentence, as is the case for the corresponding English subject-predicate structure seen in the translation.

\section{THE COMMUNICATIVE FUNCTION OF TOPIC MARKING}

Full clauses make up a sizable proportion (35.5\%) of topic-marked constituents in these two texts. Once again, a clause in this study is considered to be a clause if it contains 
either a verbal or stative predicate, or is understood to be propositional. This high proportion of clauses as topics may be of some surprise initially, because we might expect that topics are essentially redundant in the sense that they mark information the signer presupposes to be readily identifiable or accessible to the addressee, and redundant information as such often takes on a reduced form (e.g. pronouns instead of the repetition of full NPs), but I suspect that because the verb in ASL tends to carry a great deal of morphological information and is essentially the nucleus of the ASL sentence, it is often the only appropriate candidate for topic marking.

One sentence from Text B (10) is a particularly good example of this.

(10) LIST SIX, DISCUSS TEACH GATHER, GROUP ASL FINISH

'This list of six items that we will be learning about together, comprises (the exercises in) ASL.'

This sentence comes almost at the end of the narrative, and begins the signer's summary. The signer has introduced six translation exercises earlier in the discourse, and has explained that the course he will be teaching entails the practice of these six exercises. All of the information in the topic constituent, then, is retrievable by the addressee, and in fact is a brief restatement of the entire discourse preceding it. But notice that there is no overt subject in the ASL sentence that corresponds to we in the English translation. Certainly the subject would be topical in this instance, perhaps so clearly topical that it is unnecessary. In any case it is common for verbs in ASL to have null arguments whether or not the verb has subject and object agreement morphology, ${ }^{5}$ and the point to consider here is that it is the entire clause that is the topic-marked constituent.

The focus of $(10)$, the reason for the sentence to be given in the first place, however, forms the comment in the topic-comment relation. The new information for the addressee is that all of the exercises, in other words all the course work, will be in ASL to the exclusion of English (the sign FINISH in this sense means 'exclusively'). Interestingly, the point was made early in the discourse that the focus of the course would be ASL, but almost 70 clauses come between the earlier statement and (10), and it can be safely assumed that while the information contained in the comment of $(10)$ is not entirely new overall in the narrative, it is not thought sufficiently retrievable by the signer to mark as a topic. As well, the point seems to be emphatic and stronger (exclusively ASL, as opposed to a focus on $\mathrm{ASL}$ ), which also qualifies it as new.

In this instance, then, the kind of constituents that qualify as topic and as comment, as well as their respective functions, are clearly exemplified. It is also clear that the relation of topic and a comment about the topic is a more appropriate description of this kind of ASL sentence, and that a relationship understood as subject-predicate does not hold. The topic in (10) sets the framework for the new information the signer wants to convey in the comment.

Topic marking in general is distinctly communicative in function, and it may be no accident that a constituent marked as a topic in ASL looks very much like a yes/no question. Recall that in Hua, as well as in at least some other languages, the same morpheme functions to mark both yes / no questions and topics. Topics in ASL function as a type of question that asks, "Do you know X?" where X may be either identifiable from the pragmatic, extra-linguistic context of the interlocutors, or from the discourse structure itself. Yes / no questions are marked in a similar, if not identical, manner in ASL, with raised eyebrows and usually a slight forward tilt of the head (Baker and Cokely 1980). There is no change in sentence structure, as compared to English, which inverts the auxiliary and subject. The similarity between yes/no questions and topic marking is perhaps supported 
further by this study because the proportion of full clauses marked as topics is high, suggesting that the full clause of the yes/no question may be the grammatical precursor of the topic in ASL.

Another phenomenon that suggests that yes/no questions and topics are related in ASL has to do with their communicative function in discourse. True yes / no questions in ASL involve the addressee because they demand a response, which entails the participation of the addressee in the discourse. The content of a yes/no question by definition is largely topical. The information the addressee is being asked to respond to must be easily retreivable, otherwise the question loses communicativeness - the addressee will not know what to respond to. Further, following Haiman (1978), the question and response act as a kind of "topic" for the speaker's next comment, as in the example in (11).

(11) a. Do you want to see the new play that's opening tonight?

b. No, not really.

a. Okay, then I'll go by myself.

The speaker in (11a) must believe that the play and its opening that evening are topical, that is, information that is known by the addressee in order for the question to be answerable. The question and response form a kind of framework for the proposed (new) information that ultimately follows. In situations such as this, the addressee's participation is active and expected.

A topic is communicative in a somewhat similar way, although there are differences in the role the topic plays in the discourse and in the expectations placed on the addressee to participate. Rather than asking about an addressee's participation in a pragmatic event as in (11), the speaker asks only about the addressee's knowledge of the event, exemplified in (12).

(12) a. Do you know about the play opening tonight?
b. Yes.
a. Wanna go?
b. No.
a. Okay, then I'll go by myself.

The first (yes/no) question in (12) enquires about what might be topical, and if it is not, notice that the ensuing dialogue cannot proceed in the same manner:

(13) a. Do you know about the play opening tonight?

b. No.

a. Wanna go? ...

This does not make communicative sense.

Topics in ASL require a less active role from the addressee. In ASL discourse among interlocutors, the use of topic marking assists the signer in negotiating through the discourse, but without extensive participation from the addressee. No response to the question-like aspect of a marked topic is necessary, although interlocutors in ASL will frequently nod or gesture that they are following the signer, thus indicating that the topic is in fact retrievable for them. If a topic is not retrievable, however, this is indicated in the negative, and the signer will backtrack, give additional identifying information until the topic becomes recognizable to the addressee, and then proceed with the ensuing comment.

An example of a clausal topic that makes reference to an entity within the pragmatic context of the interlocutors is (14), from Text $B$.

(14) THIRD B-T-S A-S-L ENGLISH, MEAN TAKE-TURN++

'Third is the Building Translation Skills: ASL/English course, which entails working back and forth between the two languages.' 
A topic such as this asks the addressee only if they are aware of the entity (or event), and in this case, the addressee would be, since the discourse is targeted to interpretation students whom the signer believes know that such a course is scheduled for the following term.

Someone interpreting this passage must be prepared for this type of grammatical device for handling the flow of information in ASL discourse. Phrasing the topic as a question, even rhetorical in nature, followed by the comment as the response supplied by the signer, as Are you aware of the Building Translation Skills: ASL/English course? This entails working back and forth between the two languages is inappropriate in the context of the situation, and borders on being condescending. It may be the case, however, that the interpreter is not in the know, and is not the intended recipient of the information, and thus does not have the opportunity to respond to the signer that the topic is not accessible, as an intended addressee might. The interpreter must surmise that the topic is effective, and give an interpretation such as the one suggested in (14).

One pragmatic topic in Text A appears not to be retrievable, and on the surface looks very much misplaced. The signer has been telling about her experience in a car accident, in which she and some of her friends were tossed about in a van as they slid, and then rolled, down an embankment. We have been told none of the friends' names, but in the middle of the story, the signer gives us (15).

(15) $\frac{\mathrm{t}}{\mathrm{D}-\mathrm{E}-\mathrm{E}}$ CL:crooked V (arc right_centre $)^{6}$ 'Dee fell from one side to the other.'

In essence, the signer says You know Dee? She ..., but we have neither been introduced to Dee in the story, nor could the signer assume that the audience - anyone viewing the videotape - would know who her friends were. What the audience has, and what an interpreter of this story would have, on their side is the common and obvious knowledge that friends do indeed have names, and so the content of this topic is not particularly difficult on this level. But aside from that, which of the several friends being discussed is Dee is unretrievable. The missing piece (which would not be of assistance to an interpreter) is that someone who knew the signer well, and who in fact knew who Dee was, was standing beside the camera when the story was recorded, and the topic was perfectly accessible to this person.

These topics, then, exemplify the type that code pragmatic content, in other words content that is external to the discourse event. Knowledge of the content is not retrievable from the discourse itself, and the addressee must have sufficient pragmatic knowledge for the topic-marked constituent to be communicative.

\section{TOPICS RETRIEVABLE FROM THE DISCOURSE EVENT}

A second major type of topic in ASL also relates to external content, but does not rely strictly on pragmatic knowledge to be identified. These topics are introduced into the discourse first as new information in constituents other than those marked as topics, but having been stated, they become available content for topic-marking later in the discourse. In Text B, the signer describes a list of six exercises that the interpretation students in his course will be practicing. In his introduction, he gives the following (16):

(16) ALTOGETHER SIX LIST.

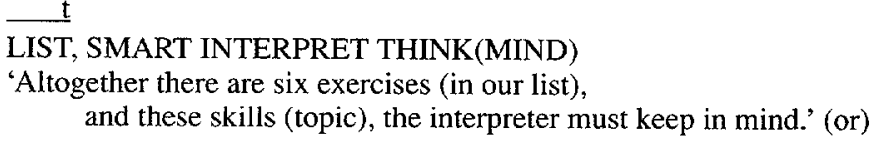


'Altogether there are six exercises (in our list),
and the interpreter must keep these skills in mind.'

Here LIST, translated first as 'exercises' and in the second sentence as the topic 'skills', is first introduced as new information, but in the sentence immediately following, LIST is chosen as the topic. Note that the context for LIST in the second sentence is internal to the discourse, and even though it refers ultimately to something in the pragmatic context (it has external meaning), it is fully identifiable by the intended addressee or by an interpreter from within the discourse event itself. Note also that the amount of lexical material coded by the topic is less than that in the sentence above ("list" rather than a "list of six items"), indicating that full retrievablility is possible from a lexically reduced "token" of the full phrase. While this kind of topic does somewhat maintain the form of a yes/no question, it is not likely that an attempt by an interpreter to phrase the interpretation as a question will be unsuccessful. The topic in this sense has been emancipated from the function of a true yes / no question. No participation of any kind would be expected from the addressee, and there would be no doubt in the mind of the signer that the topic would be identifiable.

In a way, it could be said that such topic-marking is "grammaticized" in that it has less of a communicative function than does a true question, and has more the role of a grammatical element. It is structural in nature, setting the framework for the information that is to follow, that is, it simply draws attention to the relation between the material in the topic and comment constituents.

A further example of this comes from Text A. The signer has just described the accident she was involved with, caused by a drunk driver. In (17) she tells of getting someone else to take her home, and what happened next.

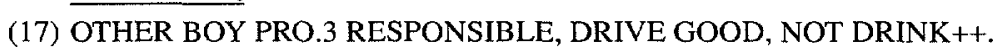

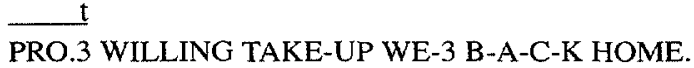

$\frac{t}{\text { PRO l ARRIVE HOME }}$

PRO.l ARRIVE HOME, PRO.1 MOTHER WORRY WHY, WHERE PRO.1 ARRIVE L-A-T-E WRONG+.

PRO.1 ARRIVE PRO.1 EXPLAIN HAPPEN.

'There was another guy who was a responsible driver, who wasn't drinking, and he was willing to take the three of us home.

I arrived home to find my mother worried about where I had been and why I was so late. I really shouldn't be getting home so late.

But I explained what had happened.'

The first topic in this segment, OTHER BOY, refers to someone at the party the signer had been at. The second reference to him, in the following sentence, is a topic-marked pronoun PRO.3, once again easily identifiable from within the discourse context. Following this, however, is an interesting set of three sentences, all of which begin similarly, but which behave somewhat differently.

In the first of these we find the clausal topic PRO.1 ARRIVE HOME, which clearly exemplifies Zubin and Li's (1986) description of topic function, that is, that a topic looks backward (is retroactive) and so builds continuity, and is forward looking (is proactive) in that it provides a framework from which to interpret subsequent discourse. PRO.1 ARRIVE HOME builds upon the event of the comment in the sentence just previous to it, in which 
the signer suggests that she was able, finally, to get home. It also sets the stage for what follows, that she found her mother distraught. This topic acts as a bridge, rephrasing known information (again, discourse internal) as the basis for what comes next.

The next instance of very similar material, PRO.1 ARRIVE L-A-T-E WRONG++ 'I really shouldn't be getting home so late', however, is not topic-marked, but perhaps it is because the signer here is referring not to the particular night in question, but is telling us something using general terms, and thus this sentence represents a shift from what is clearly topical to something, in her mind, new to the story.

In the last sentence, the signer once again employs topic marking for PRO.1 ARRIVE. This topic, another instance of a lexically reduced "token" (the object HOME is not present) of previously stated and highly retrievable material, represents another topic switch back to the event of interest. This passage seems to indicate that topic marking is a grammatical device to identify a shift in reference point, but not one that can be used to introduce an entirely new entity or idea into the discourse.

\section{DISCUSSION}

While signed languages such as ASL are seen to have many linguistic features comparable to spoken languages, it is clear they differ in some substantial ways. That signed languages involve gesture is in itself not necessarily the defining difference (cf. Armstrong, Stokoe and Wilcox (1995), who suggest that spoken languages are essentially systems of gesture as well). However, the mapping of syntax and morphology onto actual threedimensional space, and the conception of the world and its description in terms of that space, may be what distinguishes signed languages from spoken language. In these terms, syntax has a very different face.

The notion that grammar is mapped onto actual space can be extended to suggest that the space in question is shared by interlocutors. ASL is a language conveyed through the visual, rather than the auditory, channel. The signer and addressee must see each other, and so an immediacy to the communication may be expected. This is borne out in grammar by the positioning of semantic material in numerous loci in the space between the interlocutors, and these loci are salient for both discourse participants. Once an entity has been established at a spatial locus by one interlocutor, it is part of the immediate syntactic and semantic system of both. That the space can become "crowded" is essentially saying that many entities can be a part of the active discourse for participants. In both Texts A and $B$ the signers not only position entities related to one scene in their signing space, but upon introducing a subsequent scene with different players, these entities are established in much the same space, and yet it is clear that the signers intend their audience to follow as they move back and forth between scenes. With the potential for numerous entities positioned in space, it is no wonder that discourse must be negotiated.

In ASL this is at least partially accomplished by topic-comment structure. Topics are invoked by speakers (of any language) for communicative reasons, based on the knowledge structures of both speaker and addressee, rather than on the structure of the text itself (Zubin and Li 1986). Topic-comment structure is a functional notion regarding the management of information flow during discourse.

As seen from the discussion of these two texts, the semantic source for topics will be from at least two distinct realms, information that is entirely pragmatic or external to the discourse event, and information that is readily accessible internally from the discourse itself. Interpreters are third party participants in whatever discourse they are interpreting and are thus not the intended recipients of information. Instead, the other active participants, for whom the discourse is intended, will undoubtedly share some external context, and will from time to time refer to it. In ASL, such material is viable for topic marking, 
LI, Charles N. and Sandra A. THOMPSON (1981): Mandarin Chinese: A Functional Reference Grammar, Berkeley, University of California Press.

PADDEN, Carol and Tom HUMPHRIES (1988): Deaf in America: Voices from a culture, Cambridge, Harvard Univesity Press.

VALLI, Clayton and Ceil LUCAS (1995): Linguistics of American Sign Language: An Introduction, 2nd Ed. Washington, D.C., Gallaudet University Press.

ZUBIN, David A. and Naicong LI (1986): "Topic, contrast, definiteness, and word order in Mandarin", In V Nikiforidou, M. VanClay, M. Niepokuj, and D. Feder (Eds.), Proceedings of the Twelfth Annual Meeting of the Berkeley Linguistics Society, February 15-17, 1986, Berkeley, Berkeley Linguistics Society. 
and the interpreter has the difficult task of managing topic-marked information as identifiable without always being able to negotiate the discourse as an intended participant.

The second source of topics is discourse internal, and this is, by far, more accessible to the interpreter. But it means that the interpreter must work to maintain the appropriate flow of information, that is, what is topical and what is not, as well as how the signer is moving from topic to topic.

Finally, it should be said that this discussion is not intended as a complete description of topics and topic marking in ASL. Some topics fit the prototype well, while others do not seem to. Some topics in ASL appear not to have any real semantic content whatsoever, such as the instances of clause linkage alluded to above, with signs like BUT or FINISH marked as topics, which seem to function strictly as grammatical connectives between clauses. How are interpreters to understand the role that these play in the ASL sentence, and in the discourse as a whole? Such challenges surely lie ahead in the pursuit of understanding more fully the grammar of ASL.

Notes

* I would like to thank the following for their contributions to, or comments on, this study: Alan Hudson, Barbara O'Dea, Barb Shaffer, Sherman Wilcox, Kyra Zimmer, Rick Zimmer and Judy McGuirk. Any error: in the interpretation of the data are exclusively mine.

1. The notation system for representing ASL in print is cumbersome but there are some conventions. English words are used to represent ASL signs, but it should be understood that scmantic equivalence is not always achieved. Signs are represented by upper case words, as in FUTURE. Two words separated by a period, as in NEXT.WEEK, represent a single sign for which two (or more) words are needed to describe it. Two words separated by a hyphen indicate a compound sign. Letters separated by hyphens, as in B-I-L-L, represent a fingerspelled word. Plus signs $(++)$ are used to indicate the repetion of the movement of the sign Topic marking is indicated by a line and a lower case " $t$ " $(t)$, meaning that the entire constituent under the notation is the topic. PRO.1, PRO.2 and PRO.3 represent first, second and third person pronouns respecively.

2. In actuality, three texts were coded as part of another study. The current discussion reports on two of these texts, which are taken from ASL signers from the same region, and therefore are considered to be of the same dialect.

3. Upper case for the word Deaf inficates a cultural label. Deaf people who consider themselves a part of the Deaf community and sign ASL are best described as having this cultural afiliation rather than strictly being deaf in an audiological sense. For more on this see Padden and Humphries (1988).

4. One explanation might be that in spontaneous discourse, not every sentence goes as planned. It may occur to the signer that an element in running text is highly topical, and the facial topic marking may be a reaction to this, even if the position of the topic-marked element does not conform to the prototype.

5. The verbal complex in (10) might be best described as a serial verb, with three actual verbs (DISCUSS, TEACH and GATHER) referring to a single complex event. Serial verbs, as such, have not been described in the linguistic literature on ASL, but in this instance this set of three verbs does not appear to be distinguishing three distinct activities.

6. CL:crooked $V$ refers to the ASL classifier for a seated person, and this sign moves in an arc from the right area of the signing space to the centre area.

\section{REFERENCES}

ARMSTRONG, David F., STOKOE, William C. and Sherman E. WILCOX (1995): Gesture and the Nature of Language, Cambridge, Cambridge University Press.

BAKER, Charlotte and Dennis COKELY (1980): American Sign Language: A Teacher's Resource Text on Grammar and Culture, Silver Spring MD, T.J. Publishers.

FRIEDMAN, Lynn A. (1976): "The manifestation of subject, object and topic in the American Sign Language", In Charles N. Li (Ed.), Subject and Topic, New York, Academic Press, pp. 126-148.

GIVÓN, Talmy (1984): Syntax: A Functional-typological Introduction, Vol. 1, Amsterdam, John Benjamins.

HAIMAN, John (1978): "Conditionals are topics", Language, 54, pp. 564-589.

JANZEN, Terry (1995a): "Differentiating topic from subject in ASL", In Marie-Christine Aubin (Ed.), Perspectives d'avenir en traduction, Winnipeg, Presses Universitaires de Saint-Boniface, pp. 57-74.

JANZEN, Terry, (1995b): The Polygrammaticalization of FINISH in ASL, MS, Winnipeg, University of Manitoba.

LI, Charles N. and Sandra A. THOMPSON (1976): "Subject and topic: A new typology of language", In Charles N. Li (Ed.), Subject and Topic, New York, Academic Press, pp. 457-489. 